\title{
ENERGETIC EVALUATION OF GREEN MANURE PREPARATION FOR ORGANIC FARMS
}

Ausra Arlauskiene $^{1}$, Danute Jablonskyte-Rasce ${ }^{1}$, Aleksandras Velykis ${ }^{1}$, Monika Toleikiene ${ }^{2}$

${ }^{1}$ Joniskelis Experimental Station, Lithuanian Research Centre for Agriculture and Forestry, Lithuania

${ }^{2}$ Institute of Agriculture, Lithuanian Research Centre for Agriculture and Forestry, Lithuania arlauskiene.ausra@gmail.com

\begin{abstract}
Organic agriculture should be based on living agro-ecological systems and cycles, where biodiversity plays an important role. Perennial legumes are often planted to supply nitrogen, enhance nutrient cycling and availability to other crops in the rotation. Legume aboveground mass is often used as green manure in crop production farms. However, in the case of large green manure and nitrogen content incorporation, it is not always possible to control the intensity of organic matter mineralization processes. It can have a deleterious effect on soil and water quality or climate change (due to $\mathrm{N}_{2} \mathrm{O}$ and $\mathrm{NH}_{3}$ losses). Therefore, there is a need for such green manure preparation methods, which could accumulate mobile nitrogen in biomass. The aim of the study is to assess preparation techniques of red clover (Trifolium pratense L.) aboveground mass as green manure, namely mulching, ensiling and composting in terms of productivity (output rate), fuel and energy costs, and the production cost. In accordance with the decreasing amount of energy used, green manures lined up as: green manure-straw compost $>$ green manure silage $>$ fresh green manure (mulching). Preparation methods affect green manure quantity and quality. The cost evaluation of green manure preparation methods revealed that ensiling of red clover mass is more expedient compared with composting.
\end{abstract}

Keywords: composting, energy input, ensiling, mulching, red clover.

\section{Introduction}

Organic farming is regarded as a prototype to enhance the sustainability of modern agriculture while decreasing environmental impacts $[1 ; 2]$. This farming method should be based on living agroecological systems and cycles, where biodiversity plays an important role [3; 4]. Due to atmospheric nitrogen fixation Fabaceae family plants are one of the main biodiversity components. Legume crops are planted to enhance cycling of $\mathrm{N}$ and other nutrients and their availability to other crops in the rotation $[5 ; 6]$. In order to use a larger amount of biological nitrogen the aboveground mass of Fabaceae family plants is used as green manure. The major part of nitrogen is found in readily degradable organic compounds [7], therefore, the improper use of green manure on organic and conventional farms entails potential losses: $\mathrm{N}$ leaching, volatilisation, denitrification, [8; 9], decrease of humus, phosphorus and other nutrients in soil [10]. Modern technologies of green manure use must be based on $\mathrm{N}$ fixation in biomass or immobilizing in soil [11-13], synchronisation of released $\mathrm{N}$ with the $\mathrm{N}$ need by plants [14], green manure mobility [15; 16], etc. The green manure technology can be divided into the following stages: 1 ) selection of plant species (or their mixtures), their cultivation and harvesting time; 2) way of preparation and storage of green manure; and 3) time and method of green manure incorporation. The largest losses of organic matter and $\mathrm{N}$ are sustained during green manure preparation/storage, incorporation into soil and degradation of the mass incorporated into soil. It is proposed that innovative practices such as the use of green manure composting and ensiling have a high potential to close the nutrient cycles in organic arable farm [12]. Carter et al. (2014) suggest that biomass ensiling/fermentation is safer for the environment (decreases $\mathrm{C}$ and $\mathrm{N}$ losses during storage) compared with composting. However, the preparation of green manure requires additional energy and labour costs. The aim of the present study is to assess preparation techniques of red clover aboveground mass as green manure, namely mulching, ensiling and composting in terms of productivity (output rate), fuel and energy costs, and the production cost.

\section{Materials and methods}

The research was carried out in the northern part of Central Lithuania lowland $\left(56^{\circ} 12^{\prime} \mathrm{N}, 24^{\circ} 20^{\prime} \mathrm{E}\right)$. The soil of the experimental site is a limnoglacial Endocalcaric Endogleyic Cambisol (Siltic, Drainic). The soil texture is clay loam on silty clay with deeper lying sandy loam. The topsoil $(0-25 \mathrm{~cm})$ is close to neutral, medium in phosphorus, high in potassium and moderate in organic carbon and in total nitrogen. Lithuania has a climate mid-way between maritime and continental. During the energetic evaluation of the green manure preparation technology the data from 
the following experiments were used: "Optimization of nitrogen cycling by using forage legumes as green manure in the organic agrosystem" (Mulch Experiment) and "Fertilisers of organic origin to increase soil productivity and viability in organic agrosystems" (Silage and Compost Experiment). The Mulch experiment design (2009-2010) included management methods of the aboveground biomass of red clover (Trifolium pratense L.): 1) mixed management (the herbage of the first cut was removed from the field, the herbage of the second and third cuts was mulched); 2) mulching (herbage was cut four times and mulched). In the years of establishment of the experiments (2009), spring barley (variety "Ula") was undersown with red clover in variety "Vyliai" at a seed rate 7.5 million ha ${ }^{-1}$. The next year perennial sward was cut for mulching at bud formation stage. Herbage for green manure was cut and spread on the soil surface (mulch). During the Silage and Compost experiment (2014.2015) mobile green manure was produced from red clover mass (cut at the beginning of flowering stage) by ensiling or composting the mass with winter wheat straw (operations and machinery are presented in Table 2). The compost was piled on 22 June 2015 from two main components: aboveground mass of red clover ( 3 parts) and winter wheat straw (1 part). Aerobic composting was used; to stimulate decomposition the pile was mixed 5 times. After 10 months the compost was used as manure. The fermentation/ensiling of red clover aboveground mass were performed as follows: the mass was cut, chopped, piled into a special trench and then pressed well to minimise the access to air as much as possible. Having completed the piling, the mass was sealed with a special film as hermetically as possible.

The aboveground mass of red clover of each cut and mulch before its ploughing-in (Mulching experiment) was measured by weighing. The aboveground mass of red clover, mulch, silage and compost were analysed for nitrogen and carbon content (Kjeldahl and Duma method). To establish the variation of mulch, silage and compost mass, mesh polychlor vinyl bags $20 \times 15 \mathrm{~cm}$ in size with a mesh diameter of $\approx 1.0 \mathrm{~mm}$ were used. During energetic evaluation of different green manure preparation technologies, energy costs per unit area - a hectare were calculated. Energetic evaluation of green manure preparation technologies was carried out for each technological operation [17]. In performing the energetic evaluation of manure preparation the rates of mechanised labour, fuel consumption, productivity of assemblies and human labour costs were applied on the basis of the most recent information [18]. This article presents the following indicators of energetic evaluation: the rate of output $\left(\mathrm{ha} \cdot \mathrm{h}^{-1}\right)$, rate of fuel consumption $\left(1 \cdot \mathrm{ha}^{-1}\right)$ and energy consumption $\left(\mathrm{MJ} \cdot \mathrm{ha}^{-1}\right)$. The article also includes a comparison of the cost $\left(\right.$ Eur $\left.\mathrm{ha}^{-1}\right)$ of different green manure preparation methods (technologies). The experimental data were processed by STAT ENG for Excel vers. 1.55. Standard error $(S x)$ was calculated at level of statistical significance $p<0.05$ based on the number of four replications.

\section{Results and discussion}

The investigations of Mulch Experiment have shown that red clover produces large aboveground mass and accumulates high levels of $\mathrm{N}$ in it (Table 1). The $\mathrm{N}$ content in soil depends on what portion of the mass is used as green manure. Intensive decomposition of Fabaceae family plant mass indicated by a narrow $\mathrm{C}$ and $\mathrm{N}$ ratio $(\mathrm{C}: \mathrm{N})$ plays a dominant role in sustainable green manure technologies. Before incorporation the mulched herbage mass on the soil surface loses $49.0 \%$ ( 2 mulching operations) and $53.1 \%$ (4 mulching operations) of its initial mass (DM). N content in mulch decreases by 20.4-29.7\%. Some part of released $\mathrm{N}$ is bound in soil or used by regrowing swards; the remaining part of $\mathrm{N}$ can turn into losses. In addition, following the incorporation of green manure, in late autumn the mineral $\mathrm{N}$ content in soil increases significantly [19], which may leach during the period when plant growth does not take place (November-March). By virtue of intensive decomposition of green manure, crop yields increase only during the first year of its impact after application [20]. Due to these reasons, it is not easy to adjust the $\mathrm{N}$ balance and maintain stable yield of crops in rotation and soil quality parameters on organic crop production farms [13].

During the Silage and Compost Experiment the influence of ensiling and composting, as methods of green manure preparation, on organic matter and $\mathrm{N}$ losses were studied. The studies showed that organic matter losses were lower in the case of red clover biomass ensiling (below $10.0 \%$ ) compared with composting with straw (49.9\%). Red clover biomass and the nutrients contained in it were preserved during ensiling, i.e. favourable conditions were created for the activity of lactic acid bacteria 
(Leuconostoc mesenteroides, Lactobacillus cellobiosus and Lactobacillus brevis) which are aerotolerant anaerobes. Contrary to organic substances $\mathrm{N}$ content was $26 \%$ lower after ensiling compared with the data before ensiling. Such change in organic matter and $\mathrm{N}$ determines a wider $\mathrm{C}$ and $\mathrm{N}$ ratio, which limits mineralisation and induces humification processes after having inserted green manure into soil.

It is suggested that aerobic composting entails significant losses of $\mathrm{C}$ and $\mathrm{N}$ as gas emissions $\left(\mathrm{NH}_{4}{ }^{+}, \mathrm{NO}_{\mathrm{x}}, \mathrm{CH}_{4}\right)$ [21] compared with fermentation. Having taken into account this fact, the compost pile was built while stacking red clover biomass and straw in alternate layers; thus, the immobilisation of released $\mathrm{N}$ was stimulated during straw decomposition. Using this method of green manure preparation resulted in high losses of organic $\mathrm{C}$ contrary to $\mathrm{N}$. Nevertheless, such compost is safe to be used as some part of the organic matter in it has started to humify and $\mathrm{N}$ is firmly bound. Therefore, the incorporation of both green manure silage and compost with straw into soil can reduce organic matter and nutrient losses to the minimum.

Table 1

Yield of red clover aboveground mass, $\mathrm{DM}, \mathrm{N}$ and $\mathrm{C} / \mathrm{N}$ in it and green manure

\begin{tabular}{|c|c|c|c|c|c|c|c|c|}
\hline \multirow{2}{*}{$\begin{array}{l}\text { Method of } \\
\text { green } \\
\text { manure } \\
\text { preparation }\end{array}$} & \multirow{2}{*}{$\begin{array}{c}\text { Cuts and } \\
\text { extras }\end{array}$} & \multicolumn{4}{|c|}{ Before green manure application } & \multicolumn{3}{|c|}{$\begin{array}{c}\text { Green manure produced } \\
\text { and nutrients } \\
\text { accumulated per } 1 \text { ha }\end{array}$} \\
\hline & & $\begin{array}{c}\text { natural } \\
\text { weight } \\
\mathbf{k g}^{\prime} \cdot \mathrm{ha}^{-1}\end{array}$ & $\underset{\mathrm{kg} \cdot \mathrm{ha}^{-1}}{\mathrm{DM}}$ & $\begin{array}{c}\mathrm{N} \\
\mathrm{kg} \cdot \mathrm{ha}^{-1}\end{array}$ & $\mathrm{C}: \mathbf{N}$ & $\begin{array}{l}\text { DM } \\
\text { kg }\end{array}$ & $\begin{array}{l}\mathbf{N} \\
\mathbf{k g}\end{array}$ & $\mathrm{C}: \mathbf{N}$ \\
\hline \multirow{4}{*}{$\begin{array}{l}\text { Mulching } \\
\text { twice }\end{array}$} & second cut & 18716 & 2664.8 & 79 & 16 & \multirow{4}{*}{$\begin{array}{l}2405 \\
\pm 115\end{array}$} & \multirow{4}{*}{$\begin{array}{l}105 \\
\pm 17\end{array}$} & \multirow{4}{*}{$\begin{array}{l}12 \\
\pm 0\end{array}$} \\
\hline & third cut & 13570 & 2050.7 & 70 & 16 & & & \\
\hline & total & 32286 & 4715.5 & 149 & 16 & & & \\
\hline & Sx & \pm 1180 & \pm 174 & \pm 20 & \pm 1 & & & \\
\hline \multirow{6}{*}{$\begin{array}{l}\text { Mulching } \\
\text { four times }\end{array}$} & first cut & 13806 & 1560.4 & 52 & 16 & \multirow{6}{*}{$\begin{array}{l}3152 \\
\pm 268\end{array}$} & \multirow{6}{*}{$\begin{array}{l}168 \\
\pm 28\end{array}$} & \multirow{6}{*}{$\begin{array}{l}11 \\
\pm 0\end{array}$} \\
\hline & second cut & 11773 & 1625.5 & 52 & 17 & & & \\
\hline & third cut & 11213 & 2121.4 & 60 & 17 & & & \\
\hline & fourth cut & 10536 & 1413.3 & 47 & 16 & & & \\
\hline & total & 47328 & 6720.6 & 211 & 17 & & & \\
\hline & Sx & \pm 1150 & \pm 168 & \pm 28 & \pm 1 & & & \\
\hline \multirow{2}{*}{ Ensiling } & \multirow{2}{*}{ one cut } & 35700 & 7280 & 169 & 13 & 6552 & 125 & 21 \\
\hline & & \pm 2450 & \pm 458 & \pm 28 & \pm 0 & \pm 418 & \pm 15 & \pm 2 \\
\hline \multirow{4}{*}{ Composting } & one cut & 30000 & 6405 & 149 & 13 & \multirow{4}{*}{$\begin{array}{l}4921 \\
\pm 247\end{array}$} & \multirow{4}{*}{$\begin{array}{l}154 \\
\pm 21\end{array}$} & \multirow{4}{*}{$\begin{array}{l}16 \\
\pm 1\end{array}$} \\
\hline & wheat straw & 4000 & 3418 & 15 & 80 & & & \\
\hline & total & 34000 & 9823 & 164 & 36 & & & \\
\hline & $\mathrm{Sx}$ & \pm 2245 & \pm 548 & \pm 32 & \pm 21 & & & \\
\hline
\end{tabular}

Note: Sx- standard error of the means for total index

In order to harvest the aboveground mass of swards grown for green manure, the same technologies and machinery used for harvesting forage swards and straw can be applied. Herbage mass mulching, cutting, chopping and loading of cuttings onto a trailer is energy consuming agricultural operations requiring larger direct energy consumption of diesel fuel (Table 2). In applying mulching technology, energy costs depended on the number of mulching operations. In ensiling red clover biomass, $48.3 \%$ of total energy costs accounted for herbage cutting, chopping and loading of cuttings onto the trailer. Another part of energy costs accounted for transporting biomass to a trench and mass pressing. Ensiling of biomass increased the fuel and energy costs 1.9 times compared with mulching four times.

The highest energy costs were achieved during the production of red clover and straw compost, i. e. respectively 3.3 and 6.4 times higher compared with ensiling of red clover mass or mulching four times. Most of the energy costs here accounted for compost mixing 5 times $(57.7 \%)$, and herbage cutting, chopping and transportation $(24.3 \%)$. In addition, the preparation of compost from 1 ha of red clover (one cut) resulted in the highest consumption of diesel fuel - 151.1 1. It can be suggested that this green manure composting technology requires high fossil fuel costs, increasing dependency on its 
export as well as increasing a threat in terms of climate change [22]. In performing two operations of biomass mulching, it's ensiling or composting only the first cut herbage (second and third cuts in mulching) is used, therefore, there is a problem of using the biomass of other cuts. Rather effective use of green manure application could be achieved by combining the ensiling of red clover biomass of the first cut with the mulching of the mass of the second and third cuts. In this case, the total energy costs would amount to $2462.5 \mathrm{MJ} \cdot \mathrm{ha}^{-1}$, which are still significantly less compared with composting.

Table 2

Evaluation of green manure preparation methods in terms of energy

\begin{tabular}{|c|c|c|c|c|c|}
\hline \multirow{2}{*}{$\begin{array}{c}\text { Green } \\
\text { manure } \\
\text { preparation } \\
\text { methods }\end{array}$} & \multirow[b]{2}{*}{ Operations and machinery } & \multirow{2}{*}{$\begin{array}{c}\text { Fuel } \\
\text { expenditure, } \\
\mathbf{l} \cdot \mathbf{h a}^{-1}\end{array}$} & \multirow{2}{*}{$\begin{array}{c}\text { Energy } \\
\text { expenditure, } \\
\mathbf{M J} \cdot \mathbf{h a}^{-1}\end{array}$} & \multicolumn{2}{|c|}{$\begin{array}{c}\text { Labour } \\
\text { expenditure }\end{array}$} \\
\hline & & & & $\begin{array}{l}\text { human } \\
\text { labour, } \\
\text { h}^{\prime} \mathbf{h a}^{-1}\end{array}$ & MJ $\cdot h a^{-1}$ \\
\hline \multirow[t]{2}{*}{ Mulching } & $\begin{array}{c}\text { Mulching twice } \\
\text { (Belarus } 820+\text { Maxio 240 UNI) }\end{array}$ & 11.80 & 503.86 & 0.91 & 1.13 \\
\hline & $\begin{array}{c}\text { Mulching four times (Belarus MTZ } \\
820+\text { Maxio 240 UNI) }\end{array}$ & 23.60 & 1007.72 & 1.82 & 2.27 \\
\hline \multirow{4}{*}{ Ensiling } & $\begin{array}{c}\text { Herbage cutting and chopping with a } \\
\text { self-propelled chopper (E 281) } \\
\text { loading cuttings on trailers }\end{array}$ & 22.17 & 946.7 & 0.46 & 0.58 \\
\hline & \begin{tabular}{|c|} 
Transportation operations \\
(Belarus MTZ $820+$ trailer - \\
capacity $10 \mathrm{t}$, distance $-4 \mathrm{~km}$ ) \\
\end{tabular} & 14.55 & 621.3 & 1.43 & 1.80 \\
\hline & Pressing (Case Puma 200) & 9.15 & 390.7 & 0.50 & 0.63 \\
\hline & Total & 45.87 & 1958.7 & 2.39 & 3.01 \\
\hline \multirow{7}{*}{ Composting } & \begin{tabular}{|c|}
$\begin{array}{c}\text { Herbage cutting and chopping with a } \\
\text { self-propelled chopper (E 281) } \\
\text { loading cuttings on trailers }\end{array}$ \\
\end{tabular} & 22.17 & 946.7 & 0.46 & 0.58 \\
\hline & $\begin{array}{c}\text { Transportation operations } \\
\text { (Belarus MTZ } 820+\text { trailer }- \\
\text { capacity } 10 \mathrm{t}, \text { distance }-4 \mathrm{~km} \text { ) }\end{array}$ & 14.55 & 621.3 & 1.43 & 1.80 \\
\hline & $\begin{array}{l}\text { Straw chopping from swathes ( } \mathrm{E} \\
281) \text {, loading cuttings on trailers }\end{array}$ & 14.30 & 610.6 & 0.9 & 1.13 \\
\hline & $\begin{array}{c}\text { Transportation operations } \\
\text { (Belarus MTZ } 820+\text { trailer - } \\
\text { capacity } 10 \mathrm{t}, \text { distance }-4 \mathrm{~km} \text { ) }\end{array}$ & 4.85 & 207.1 & 0.5 & 0.63 \\
\hline & \begin{tabular}{|c|} 
Mass mixing with a front-end loader \\
5 times (Belarus $820+$ \\
Stoll Ecoline F850P) \\
\end{tabular} & 87.20 & 3723.4 & 2.0 & 12.6 \\
\hline & $\begin{array}{c}\text { Water transportation (Valtra T } 130+ \\
\text { tank - capacity } 10 \mathrm{~m}^{3} \\
\text { distance }-4 \mathrm{~km}) \\
\end{array}$ & 8.0 & 340.8 & 2.0 & 2.52 \\
\hline & Total & 151.07 & 6449.9 & 7.29 & 19.26 \\
\hline
\end{tabular}

In terms of labour efficiency there were no significant differences between biomass mulching, cutting, chopping and loading on trailers. Operations of the lowest factual efficiency were biomass transportation from the field operations and mixing of the compost pile (especially during the first three times). Biomass ensiling requires insignificantly higher human labour and energy costs $(31.3 \%)$, compared with intense mulching (4 times). Composting of red clover mass with straw consumes 4.0 times more man-hours and 3.1 times more energy compared with mulching four times or ensiling.

The cost of green manure production per hectare was similar to energy consumption. The cost of biomass composting with straw was significantly higher compared with its mulching or ensiling (Table 3). It would be expedient to search for less energy consuming composting technologies (such as microbiological, anaerobic ones, etc.). 
Economic evaluation of green manure preparation methods

\begin{tabular}{|l|c|c|c|}
\hline $\begin{array}{c}\text { Green manure } \\
\text { preparation methods }\end{array}$ & $\begin{array}{c}\text { Production cost of green } \\
\text { manure, EUR } \cdot \mathbf{h a}^{-\mathbf{1}}\end{array}$ & $\begin{array}{c}\text { Cost of 1 t of green } \\
\text { manure DM, EUR }\end{array}$ & $\begin{array}{c}\text { Cost of 10 kg N, } \\
\text { EUR }\end{array}$ \\
\hline Mulching twice & 27.66 & 11.50 & 2.63 \\
\hline Mulching four times & 55.32 & 17.55 & 3.29 \\
\hline Ensiling & 118.20 & 18.04 & 9.45 \\
\hline Composting & 374.48 & 76.10 & 24.32 \\
\hline
\end{tabular}

In terms of green manure preparation methods, it was found that the cost of one t DM of ensiled green manure differed insignificantly from the cost of mulched biomass. However, in terms of the cost of accumulated $\mathrm{N}$, it can be stated that the cheapest $\mathrm{N}$ is obtained by biomass mulching, and the most expensive way in this respect is composting with straw. However, ensiled and composted green manures are mobile - environmentally safe methods of their application and time can be adjusted.

\section{Conclusions}

1. The following methods of green manure preparation: biomass mulching on the soil surface, ensiling of biomass and composting it with straw determines different $\mathrm{C}$ or nutrient losses. Red clover biomass mulching determined $\mathrm{C}$ and $\mathrm{N}$ losses, biomass composting with straw determined $\mathrm{C}$ losses and ensiling $-\mathrm{N}$ losses. The largest losses were sustained by mulching and composting red clover biomass.

2. Aerobic red clover biomass composting with straw is highly consuming in terms of energy. Preparation of compost requires 6.4 times more energy and 4.0 times more man-hours compared with mulching four times. The major part of energy costs accounted for compost pile mixing five times. This green manure composting technology requires high fossil fuel costs, which is not acceptable for organic farming. Red clover biomass ensiling in a trench results in $69.65 \%$ lower energy consumption compared to composting. Rather effective use of green manure application could be achieved by combining ensiling of red clover biomass of the first cut with mulching of the mass of the second and third cuts. In this case, the total energy costs would amount to 2462.5 MJ.ha ${ }^{-1}$, which are still significantly less compared with composting.

3. Both in terms of the cost of $1 \mathrm{t} \mathrm{DM}$ of green manure and $10 \mathrm{~kg} \mathrm{~N}$, red clover biomass ensiling is cheaper compared to composting. Ensiled and composted green manures are mobile environmentally safe methods of their application and time can be adjusted.

\section{References}

1. Darnhofer I., Lindenthal T., Bartel-Kratochvil R. etc. Conventionalisation of organic farming practices: from structural criteria towards an assessment based on organic principles. A review. Agronomy for Sustainable Development, vol. 30, Nr. 1, 2010. pp. 67-81.

2. Jensen E.S., Bedoussac L., Carlsson G. etc. Enhancing yields in organic crop production by ecofunctional intensification. Sustainable Agriculture Research, vol. 4, Nr. 3, 2015, pp. 42-49.

3. IFOAM (2005): Participatory Guarantee Systems: shared vision, shared ideals, http://www.ifoam.org/about_ifoam/standards/pgs/pdfs/PGSConceptDocument.pdf. (accessed 2016-12-23).

4. Hole D.G., Perkins A.J., Wilson J.D. etc. Does organic farming benefit biodiversity? Biological Conservation, 122, 2005, pp. 113-130.

5. Dawson J., Huggins D.R., Jones S.S. Characterizing nitrogen use efficiency in natural and agricultural ecosystems to improve the performance of cereal crops in low-input and organic agricultural systems. Field Crops Research, vol. 107, 2008. pp. 89-101.

6. Preissel S., Reckling M., Schläfke N. etc. Magnitude and farm-economic value of grain legume pre-crop benefits in Europe: A review. Field Crops Research, vol. 175, 2015, pp. 64-79.

7. Fuchs J.G., Schleiss K. Auswirkungen von Komposten und von Gärgut auf die Umwelt, Bodenfruchtbarkeit, sowie die Pflanzengesundheit: Ökologische Bewertung der organischen Substanz. Schlussbericht (Impact of composted and fermented organic matter on in environment, 
soil fertility and plant healthy: ecological assessment of organic materials. Final report). FiBL, 2009. 37 p. (In German).

8. Olesen J.E., Askegaard M., Rasmussen I.A. Winter cereal yields as affected by animal manure and green manure in organic arable farming. European Journal of Agronomy, 30, 2009, pp. 119-128.

9. Pinder R.W., Bettez N.D., Bonan G.B. etc. Impacts of human alteration of the nitrogen cycle in the US on radiative forcing. Biogeochemistry, 2012, pp. 1-16.

10. Lynch D.H. Nutrient cycling and soil health in organic cropping systems-importance of management strategies and soil resilience. Sustainable Agriculture Research, vol. 4, Nr. 3, 2015, pp. 80-86.

11. Aguilera E., Lassaletta L., Sanz-Cobena A. etc. The potential of organic fertilizers and water management to reduce $\mathrm{N}_{2} \mathrm{O}$ emissions in Mediterranean climate cropping systems. A review. Agriculture, Ecosystems and Environment, 164, 2013, pp. 32-52.

12. Odokonyero K. Soil carbon retention and nitrogen mineralization in organic farming systems using different green manure management. ECTS Master Thesis, 2013. 84 p.

13. Carter M.S., Sorensen P., Petersen S.O. etc. Effects of green manure storage and incorporation methods on nitrogen release and $\mathrm{N}_{2} \mathrm{O}$ emissions after soil application. Biology and Fertility of Soils, 2014, vol. 50, pp. 1233-1246.

14. Crews T. E., Peoples M. B. Can the synchrony of nitrogen supply and crop demand be improved in legume and fertilizer-based agroecosystems. Nutrient Cycling in Agroecosystem, vol. 72, Nr. 2, 2005, pp.101-120.

15. Tripolskaja L., Šidlauskas G. The influence of catch crops for green manure and straw on the infiltration of atmospheric precipitation and nitrogen leaching. Žemdirbystė-Agriculture, vol. 97, Nr. 1, 2010, pp. 83-92.

16. Velykis A., Satkus A., Masilionyte L. Effect of tillage, lime sludge and cover crop on soil physical state and growth of spring oilseed rape (Brasica napus L.). Žemdirbystė=Agriculture, vol. 101, Nr. 4, 2014, pp. 347-354.

17. Jasinskas A. Žolinių augalų kuro ruošimo technologijų energetinis vertinimas (Energy assessment of herbaceous plant fuel production technologies). Lithuanian Scientific Journal of Agricultural Engineering: Žemès ūkio inžinerija, mokslo darbai, 2003, vol. 35, No. 4, pp. 70-81. (In Lithuanian).

18. Mechanizuotų žemės ūkio paslaugų ịkainiai (Mechanized agricultural service fees). Lithuanian Institute of Agrarian Economics, 2016. Parts 1, 2 and 3. (In Lithuanian). [online] [13.03.2017]. Available at: http://www.laei.lt/?mt=aktualijos\&naujiena $=415$

19. Nemeikšienė D., Arlauskienè A., Šlepetienė A. etc. Mineral nitrogen content in the soil and winter wheat productivity as influnced by the pre-crop grass species and their management. Zemdirbyste-Agriculture, vol. 97, No. 4, 2010, pp. 23-36.

20. Arlauskienè A., Šlepetienė A., Nemeikšienė D. Pupinių žolių antžeminès masės, panaudotos žaliajai trąšai, poveikis anglies ir azoto pokyčiams glejjiškame rudžemyje (Effect of the aboveground mass of legumes applied for the green manure on carbon and nitrogen change in Gleyic Cambisol). Agricultural Sciences: Žemès ūkio mokslai, vol. 20, No. 4, 2013, pp. 241-252. (In Lithuanian).

21. Möller K.; Schultheiß U. Organische Handelsdüngemittel im ökologischen Landbau. Charakterisierung und Empfehlungen für die Praxis (Organic commercial fertilizers in organic farming. Characteristics and recommendations for practice). KTBL-Schrift 499, Darmstadt, 2014. 392 p. (In German).

22. Bessou, C., Ferchaud, F., Gabrielle, B. etc. Biofuels, greenhouse gases and climate change. Agronomy for Sustainable Development, Vol. 2, 2011, pp. 1-79. 